\title{
Impact of Micro Finance Activities on the Economic Development of Bangladesh
}

\author{
Md Sazzadur Rahman Khan ${ }^{1}$, Rezaul Karim ${ }^{2}$ \\ ${ }^{1}$ Department of Business Administration, Stamford University Bangladesh, Dhaka, Bangladesh \\ ${ }^{2}$ Department of Business Administration, Atish Dipankar University of Science and Technology, Dhaka, Bangladesh \\ Email address: \\ tipu06bd@yahoo.com (Md S. R. Khan), rezaul.karim00@gmail.com (R. Karim)
}

\section{To cite this article:}

Md Sazzadur Rahman Khan, Rezaul Karim. Impact of Micro Finance Activities on the Economic Development of Bangladesh. International Journal of Finance and Banking Research. Vol. 2, No. 1, 2016, pp. 1-6. doi: 10.11648/j.jifbr.20160201.11

\begin{abstract}
The study was conducted to find out how microfinance plays the pivotal role and what significant impact on the development of Bangladesh. To observe that we tried to find out in which way it is playing its role and what type of key economic development indicators are related with it. Microfinance is providing a significant role in the development of Bangladesh by providing financial assistance to the lower income but self-employed people. Once most of these people were remained unemployed but by getting the financial support from the different institutions especially from Grameen Bank and other similar NGOs like BRAC they have turned into employed. The poverty level has minimized a lot from the rural area and household income increase by around one-third. Wages and marginal propensity to consumption increased especially for women and it creates positive impact on children's schooling: A 1.05\% increase in Grameen Bank female borrowers increases the probability of school enrollment by $1.8 \%$ for girls and $1.99 \%$ for boys. Microfinance also contributed to smoothening consumption level and reducing vulnerability of life of people.
\end{abstract}

Keywords: GDP, IDFID, MFI, Micro Finance, Economic Development

\section{Introduction}

Microfinance, according to Otero (1999, p. 8) is "the provision of financial services to low-income poor and very poor self-employed people". These financial services according to Lidgerwood (1999) generally include savings and credit but can also include other financial services such as insurance and payment services. Schreiner and Colombet (2001, p. 339) define microfinance as "the attempt to improve access to small deposits and small loans for poor households neglected by banks." Therefore, microfinance involves the provision of financial services such as savings, loans and insurance to poor people living in both urban and rural settings who are unable to obtain such services from the formal financial sector. In the literature, the terms microcredit and microfinance are often used interchangeably, but it is important to highlight the difference between them because both terms are often confused. Sinha (1998, p. 2) states "micro credit refers to small loans, whereas microfinance is appropriate where NGOs and MFIs1 supplement the loans with other financial services (savings, insurance, etc.)". Therefore micro credit is a component of Microfinance in that it involves providing credit to the poor, but Microfinance also involves additional non-credit financial services such as savings, insurance, pensions and payment services (Okio credit, 2005).

\section{Literature Review}

Shahidur R. Khandker (1998) describes as, providing the poor with access to financial services is one of many ways to help increase their incomes and productivity. In many countries, however, traditional financial institutions have failed to provide this service (Adams, Graham, and Von Pischke 1984; Braverman and Guasch 1986, 1989; Hoff and Stiglitz 1990; World Bank 1975, 1993) and cooperative programs have been developed to fill this gap. Their purpose is to help the poor become self-employed and thus escape poverty. Many of these programs provide credit using social mechanisms, such as group-based lending, to reach the poor and other clients, including women, who lack access to formal financial institutions (Huppi and Feder, 1990; Von Pischke, Adams, and Donald, 1983; Yaron, 1994). With increasing assistance from the World Bank and other donors, microfinance is emerging as an instrument for reducing poverty and improving the Poor's 
access to financial services in low-income countries (World Bank, 1990; Binswanger and Landell-Mills, 1995). Shahidur R. Khandker (1998) also pointed out by illustrating as; Poverty is often the result of low economic growth, high population growth, and extremely unequal distribution of resources. The proximate determinants of poverty are unemployment and the low productivity of the poor. When poverty results from unemployment, reducing poverty requires creating jobs; when poverty results from low productivity and low income, reducing poverty requires investing in human and physical capital to increase workers' productivity. In many countries, such as Bangladesh, poverty is caused by lack of both physical and human capital. Consequently, the best way to reduce poverty is to deal with both problems: increasing productivity by creating employment and developing human capital. Lack of savings and capital make it difficult for many poor people who want jobs in the farm and nonfarm sectors to become self-employed and to undertake productive employment-generating activities. Providing credit seems to be a way to generate self-employment opportunities for the poor. But because the poor lack physical collateral, they have almost no access to institutional credit. Informal lenders play an important role in many low-income countries (Adams and Fitchett, 1992; Ghate, 1992), but they often charge high interest rates, inhibiting poor rural households from investing in productive income- increasing activities. Moreover, although informal groups, such as Rotating Savings and Credit Associations, can meet the occasional financial needs of rural households in many societies, they are not reliable sources of finance for income-generating activities (Webster and Fidler, 1995). Micro credit programs are able to reach the poor at affordable cost and can thus help the poor become self employed. Proponents of micro credit consider increasing the Poor's access to institutional credit an important means of ending poverty (Yunus, 1983). They argue that by virtue of their design such programs can reach the poor and overcome problems of credit market imperfections. In their view improved access to credit smoothes consumption and eases constraints in production, raising the incomes and productivity of the poor. Empirical studies support this view to some extent: credit market interventions improve both the consumption and production of the poor who otherwise lack access to credit (Feder and others, 1988: Foster, 1995; Rosenzweig and Wolpin, 1993). According to proponents of micro credit, when traditional banks and financial institutions fail to meet the needs of women and the poor, alternative institutions should be developed to meet these groups' demand for financial services. It is explicit that micro financing in Bangladesh is crucial; it has been playing a major role not only for the economic development, but also indicates the necessity to develop the rural financial markets. It is such an effective tool that can be used as a strategy for the poverty reduction, improve the institutional microfinance system, financial markets, empower the poor women, etc. ADB report 2000 on The Rural Asia study states that; "In spite of the rapid growth of microfinance services, Rural Financial Markets in Asia are ill-prepared for the twenty-first century. About 95 percent of some 180 million poor households in the Asian and Pacific Region (the Region) still have little access to institutional financial services". Development practitioners, policy makers, and multilateral and bilateral lenders, however, recognize that providing efficient microfinance services for this segment of the population is important for a variety of reasons which are mentioned as follows (ADB report, June 2000): "Rural Asia Study, Beyond the Green Revolution.” Manila, ADB.

\section{Objectives of the Research}

The major objectives of the present research include the following:

- To identify the major economic development indicators of micro finance.

- To suggest some policy measures for more effective implementation of the micro finance programs.

\section{Methodology of the Research}

This research is a descriptive type of research that has undertaken insights and understanding about overall operation of economic development of Bangladesh and prepared on the basis of primary and secondary sources. The relevant information was collected through direct interview of the personnel engaged in various departments of Gramen Bank \& other NGOs. The secondary information was collected from different past files, which were collected from personal visit of the company files.

\section{Major Economic Development Indicators}

The major economic development indicators include the following:

\subsection{GDP Growth}

Bangladesh's economy has been experiencing both the macroeconomic firmness as well as strong economic growth due to the transition to a democratic rule in the country in early1990s. During the late 1980s Bangladesh's deep Macroeconomic crisis, a sequential stabilization measures were launched in the Bangladesh economy which mainly restored the macroeconomic stability in the early 1990s. Figure1\&table1) demonstrates that; the GDP annual growth rate starts from 3 percent in 1994, 5 percent both in 1996 and 1997. Then it dropped to 4 percent in 1998. After that again it gained a stable growth rate of 5 percent between 1999 and 2003. Followed by from the year 2005 to 2011; the GDP growth rates were almost increasing from 5 percent to 7 percent nevertheless it dropped to 4 percent in 2007 . 


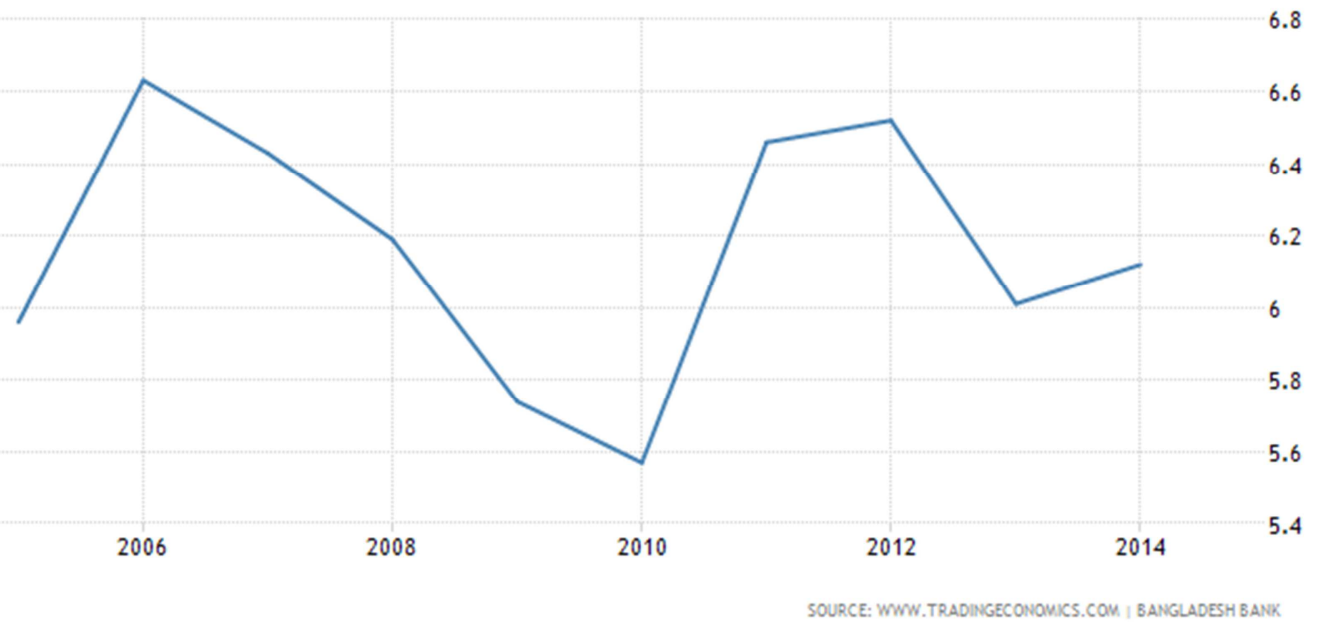

Figure 1. Bangladesh GDP Annual Growth Rate.

The following figure (see table 2) displays the GDP per capital annual growth rate in 2001 it was only 1 per cent and the following years by and large growth rates are almost amazing. In 2009 it reached to 5 percent; indicating a great potential achievement of the ongoing development of Bangladesh. This means a lot; in general more people are earning more than that of last decades.

Table 1. Bangladesh's GDP growth (\%) from 1996 to 2014.

\begin{tabular}{llllllll}
\hline Year & GDP growth rate & Year & GDP growth rate & Year & GDP growth rate & Year & GDP growth rate \\
\hline 1996 & 4.5 & 2001 & 5.1 & 2006 & 6.7 & 2011 & 6.5 \\
1997 & 4.5 & 2002 & 3.8 & 2007 & 7.1 & 2012 & 6.5 \\
1998 & 5.2 & 2003 & 4.7 & 2008 & 6.0 & 2013 & 6.0 \\
1999 & 4.7 & 2004 & 5.2 & 2009 & 5.0 & 2014 & 6.1 \\
2000 & 5.3 & 2005 & 6.5 & 2010 & 5.6 & & \\
\hline
\end{tabular}

As a result it is helping the poor to defeat their poverty by reducing the income inequality and their vulnerability. In this regard we adjoin Sadiq Ahmed's (2011) 19 Comparative Analysis on South Asia's development performance in terms of GDP growth indicator. A portion of his table 3 of GDP growth per capital during1960-2011 among the South Asian countries in his report makes relevant with my viewpoint; hence it is presented in my report as follows as table 3 .

Table 2. Bangladesh's GDP per capital growth (\%) from 1996 to 2014.

\begin{tabular}{llllllll}
\hline Year & $\begin{array}{l}\text { GDP growth rate } \\
\text { (per capital) }\end{array}$ & Year & $\begin{array}{l}\text { GDP growth rate } \\
\text { (per capital) }\end{array}$ & Year & $\begin{array}{l}\text { GDP growth rate } \\
\text { (per capital) }\end{array}$ & Year & $\begin{array}{l}\text { GDP growth rate } \\
\text { (per capital) }\end{array}$ \\
\hline 1996 & 2.3 & 2001 & 3.1 & 2006 & 5.3 & 2011 & 5.2 \\
1997 & 2.3 & 2002 & 2.0 & 2007 & 5.8 & 2012 & 5.3 \\
1998 & 3.0 & 2003 & 2.9 & 2008 & 4.8 & 2013 & 4.7 \\
1999 & 2.6 & 2004 & 3.6 & 2009 & 3.9 & 2014 & 4.8 \\
2000 & 3.3 & 2005 & 5.0 & 2010 & 4.4 & & \\
\hline
\end{tabular}

As Sadiq Ahmed (2011) says," Within South Asia, differences in per capital income expansion appear less striking; this is because all the major countries in the region, including Nepal, experienced positive growth in per capital incomes".

Table 3. Per Capital GDP Growth rate, South Asian Countries, 1960-2011.

\begin{tabular}{lllllll}
\hline (\% per year) & & & & & \\
\hline Country & $\mathbf{1 9 8 6 - 9 6}$ & $\mathbf{1 9 9 0 - 2 0 0 6}$ & $\mathbf{2 0 0 0 - 0 9}$ & $\mathbf{1 9 9 0 - 2 0 0 9}$ & $\mathbf{1 9 6 0 - 2 0 1 1}$ & Source: \\
\hline Bangladesh & 1.1 & 3.0 & 3.2 & 3.1 & $2.0^{* *}$ & World Bank Central \\
India & 3.6 & 3.6 & 4.3 & 3.8 & 2.5 & database. \\
Nepal & 2.4 & 2.6 & 0.3 & 2.5 & 1.3 & ** refers to 1978-2011 as \\
Pakistan & 3.5 & 1.4 & 1.3 & 1.4 & 2.5 & Sadiq Ahmed mentioned. \\
Sri Lanka & 3.1 & 3.9 & 1.3 & 3.3 & 2.8 & \\
\hline
\end{tabular}


So the implication of this per capital growth rates signify us about the income levels have developed a lot for the individual countries in the SAARC 23 region. Consequently the South Asian rising share of global income indicates us about the regions progress besides making relative to the rest of the world. So, what we have told before is true that; Bangladesh's macro economy started develop into stable in the early 1990s; because it gained momentum. However, important differences are apparent in growth experiences between countries and over time, Bangladesh's GDP per capital growth rates (see table 2) showing eventually a positive sign of increasing the income level over time. For this reason, I can see that microfinance is not a constraint for increasing the per capital income level but generates to increase the income for the poor in Bangladesh.

\subsection{Savings}

The World Bank's WDI24 data demonstrates Bangladesh's a relative improvement of both Gross Domestic Savings (GDS) and Gross Savings (GS) among the SAARC countries between 1994 and 2009. The statistics proves that both the GDS and the GS rates of Bangladesh have a dramatic progress during that period. Firstly, both the GDS and the GS rates of Bangladesh between 1994 and 1999 were relatively one of the lowest among the SAARC countries; the fact was sluggish growth rates. Secondly In contrast, having a look at both of the figures during the period 2000-'09; Bangladesh's GDS rate as well as the GS rates are nearly in full swing; and thus overtook other countries except India and Nepal until 2009. For instance, Bangladesh stands relatively the second highest in terms of GDS rate just behind of India and exceeded Pakistan and Sri Lanka by 2006. Thirdly, the GS rate of Bangladesh reached up to the third top level having behind of India and Nepal respectively since 2008; but it left behind Pakistan and Sri Lanka since 1999, which demonstrate an impressive improvement of Bangladesh's economy among the SAARC member countries.

The table 6 displays the Gross National Savings (GNS) of Bangladesh between 2007-8 and 2009-10. It is obvious from the GNS of Bangladesh has been increasing very robustly from 2005-7 till the subsequent years until 2010-11. For instance in 2007-8 Bangladesh's GNS was 25.44 percent of GDP and by virtue of linearly increasing; the GNS of Bangladesh reached at 29.15 percent of GDP in 2010-11 although it is a provisional rate.

Table 4. GDS (\% of GDP) of the SAARC countries.

\begin{tabular}{llllll}
\hline Year & Bangladesh & India & Nepal & Pakistan & Sri Lanka \\
\hline 1996 & 11 & 22 & 10 & 17 & 14 \\
1997 & 13 & 23 & 11 & 17 & 15 \\
1998 & 13 & 21 & 14 & 15 & 16 \\
1999 & 14 & 23 & 15 & 17 & 15 \\
2000 & 13 & 25 & 15 & 16 & 15 \\
2001 & 12 & 21 & 14 & 14 & 15 \\
2002 & 15 & 21 & 14 & 13 & 17 \\
2003 & 17 & 20 & 14 & 17 & 19 \\
2004 & 17 & 24 & 14 & 14 & 19 \\
\hline
\end{tabular}

\begin{tabular}{llllll}
\hline Year & Bangladesh & India & Nepal & Pakistan & Sri Lanka \\
\hline 2005 & 18 & 23 & 15 & 16 & 17 \\
2006 & 17 & 23 & 15 & 16 & 16 \\
2007 & 18 & 24 & 12 & 17 & 14 \\
2008 & 18 & 25 & 12 & 18 & 16 \\
2009 & 19 & 30 & 13 & 18 & 16 \\
2010 & 18 & 32 & 12 & 14 & 15 \\
2011 & 18 & 33 & 14 & 9 & 16 \\
2012 & 20 & 30 & 11 & 7 & 15 \\
2013 & 21 & 30 & 10 & 8 & 17 \\
2014 & 23 & 29 & 9 & 8 & 20 \\
\hline
\end{tabular}

Table 5. GS (\% of GDP) of the SAARC countries.

\begin{tabular}{lllll}
\hline Bangladesh & India & Nepal & Pakistan & Sri Lanka \\
\hline 16 & 22 & 16 & 26 & 17 \\
20 & 23 & 16 & 25 & 20 \\
20 & 22 & 20 & 21 & 21 \\
21 & 24 & 18 & 22 & 20 \\
21 & 27 & 22 & 21 & 20 \\
20 & 23 & 21 & 18 & 19 \\
22 & 23 & 22 & 18 & 22 \\
24 & 21 & 23 & 21 & 24 \\
25 & 26 & 27 & 17 & 24 \\
27 & 26 & 33 & 19 & 17 \\
25 & 26 & 35 & 19 & 21 \\
29 & 27 & 33 & 20 & 20 \\
30 & 28 & 32 & 23 & 22 \\
31 & 32 & 32 & 22 & 22 \\
30 & 34 & 33 & 21 & 20 \\
33 & 36 & 35 & 17 & 21 \\
38 & 35 & 40 & 21 & 22 \\
40 & 32 & 40 & 20 & 24 \\
39 & 32 & 43 & 21 & 26 \\
\hline
\end{tabular}

Table 6. Gross National Savings (GNS) (\% of GDP) of Bangladesh.

\begin{tabular}{llll}
\hline Year & GNS (\% of GDP) & Year & GNS (\% of GDP) \\
\hline $2007-08$ & 25.44 & $2011-12$ & 29.40 \\
$2008-09$ & 25.84 & $2012-13$ & 30.06 \\
$2009-10$ & 27.67 & $2013-14$ & 30.38 \\
$2010-11$ & 29.15 & $2014-15$ & 30.04 \\
\hline
\end{tabular}

Several surveys have estimated the size of savings in these areas. As part of the Rural Finance Project of Bangladesh Bank (the central bank), Maloney and Ahmed (1998) conducted a survey of 300 households' savings as did the people themselves (cash savings) in rural Bangladesh. The survey shows that the poor save between $2 \%$ and $12 \%$ of their income; with the moderately poor saving an average of $12 \%$ to $14 \%$. The survey found that buying land was cited as the most important reason for saving, followed by providing family security against unforeseen contingencies. The education and marriage of children along with the purchase of agricultural inputs were other factors found to influence savings. R.I. Rahman (2001a) conducted a survey of 370 households in two villages to estimate the rural households' demand for liquid savings services. The average savings rate was $9 \%(16.6 \%$ in one village and $-5.5 \%$ in another village); savings was defined as the difference between estimated income and consumption expenditures of the household. It revealed that, a sizable portion of savings was directly invested in asset build-up. Female respondents suggested that 
the purchase of various assets such as livestock and land, and the future needs of the family and children are the major incentives for the savings. The survey also revealed some demand for long-term savings. The brief surveys reported here provide an introduction to the salient feature of savings in rural Bangladesh. They show that households in Bangladesh rarely save for life cycle events such as retirement; instead people expect their children to take care of them in old age. The savings, which are small relative to income, are used frequently to close the gap between consumption and uncertain income (Rutherford, 2002). The survey was unable to capture the level of savings that would have resulted if MFIs were available to collect savings. Strictly speaking, micro financing is not a constraint for the economic development in Bangladesh. As Harper, M. (2007)32 says, "Domestic Savings provide the assets for the economy's investment in future production. Without them, the economy cannot grow unless there are alternative sources of investment." Hubka, A.; R. (2010)33 says as "Microfinance is a credit methodology, which employs effective collateral substitute for short-term and working capital loans to micro-entrepreneurs". Fallavier, P. (2003)34 said "the level of countries poverty has long been linked with measures of its economic development. Little consideration was given to the social reorganization of the natural resources (e.g. empowerment vs. alienation of people, sustainable vs. depletion of the environment)". And (Khan, Penn, F. (2007)35 stated that; "The economies with positive growth rate of GNP were measured by their poverty mitigation. This gratitude emphasized on the achievement of wealth and technology as a path for development and assumed that improved lives for all would be the natural consequence". In this connection I provide an evidence of Grameen Bank's contribution in terms of GDP rising in Bangladesh as follows: Dowla and Barua (2008) describes36 as "since the Grameen Bank operates throughout the country with large numbers of borrowers, it should affect economic transactions in the whole economy. One study attempted to compute the impact of Grameen Bank on Bangladesh's GDP. Dr. Mohiuddin Alamgir, who was the director of the Policy and the Planning Division of the United Nations International Fund for Agricultural Development between 1987 and 1999, claimed that Grameen Bank raised the GDP of Bangladesh by as much as 1.10-1.50\% between 1995 and 1996. Grameen's more important contribution lies in its impact on improving social welfare and reducing poverty, which might ultimately have the greatest effect on GDP in the long run. In order to answer this question, I provide an evidence of Grameen Bank's borrowers and theirs' conquer of Poverty Line according to the bank's ten indicators.

Table 7. The percentage of borrowers moving out of poverty on the basis of the bank's ten indicators.

\begin{tabular}{llllll}
\hline Year & Percent above the poverty line & Year & Percent above the poverty line & Year & Percent above the poverty line \\
\hline 2003 & 15.1 & 2007 & 42.0 & 2011 & 2012 \\
2004 & 20.4 & 2008 & 46.5 & 58.4 \\
2005 & 24.1 & 2009 & 51.1 & 2013 & 56.2 \\
2006 & 40.0 & 2010 & 55.0 & 2014 & 58.6 \\
\hline
\end{tabular}

Obviously not the constraint for the economic development indicators, in contrast; it is significantly narrowing the income distribution scenario of Bangladesh economy by supporting the Poor's GDP rising as well as marginal savings rising through microfinance. Consequently poor are coming out from the poverty in Bangladesh. It is worth mentioning here that; according to the GB's recent internal survey 6839 percent of Grameen borrowers' families have crossed the Poverty Line, the remaining are moving steadily towards the Poverty Line from below.

\section{Findings}

- $5.5 \%$ of Grameen Bank and $2.99 \%$ of BRAC households rose to poverty level.

- Household income increase by $31 \%$ and $35 \%$ for Grameen Bank and BRAC borrowers respectively.

- Wages in Grameen villages and self-employment in off-farm activities increases.

- Marginal propensity to consumption increased (18\% for women; $11 \%$ for male borrowers).

- $10 \%$ increase in BRAC credit increased household net worth by $0.09 \%$ and $0.14 \%$ for female borrowers.

- Positive impact on children's schooling: A $1.5 \%$ increase in Grameen Bank female borrowers increases the

- Probability of school enrollment by $1.8 \%$ for girls and $2.5 \%$ for boys.

- Micro credit contributed to smoothening consumption and reducing vulnerability.

\section{Recommendation}

Remittances are one of the major sources of the foreign currency earning of Bangladesh. Remittances play a significant role for the balance of payment as well as economic development of the country. The government and also donor communities have given proper emphasis for boosting remittances flow. Recently Department For International Development (DFID) of UK government has proposed for funding a project to increase the official channels of remittances flowing Bangladesh. Although the government has undertaken several initiatives to increase remittances flow, but still something more to do. Moreover, Bangladesh is role model and considered as pioneer in Microfinance. Many Microfinance Institutes (MFIs) and Non-Government Organizations (NGOs) are operating in Bangladesh. But still this remittance sector is untapped by them. The following recommendations can be helpful for harnessing remittances for the economic development of 
Bangladesh:

- Establish more technical institutes: The government as well as private sector can establish more high quality technical, polytechnics and vocational institutes that can supply skilled and professional personnel.

- Develop new foreign policy: The government should develop new foreign policy and assigned a professional person at each diplomatic mission office abroad to explore the potentials of manpower export in that country and properly lobby with different concerned persons of that country. At present although the government has a post of labor attaché in diplomatic mission of some countries, but still it is insignificant.

- Utilization of Remittances in productive investment: The government as well as private sectors specially the MFIs/NGOs can come forward in this regard. At present one $\mathrm{NGO}$ is playing role of transferring remittances. But the MFIs/NGOs need to do more beyond transfer. The government should eliminate regulatory constraint of transferring remittance for MFIs/NGOs. The government as well as MFIs/NGOs can provide Business Development Services to the remittances recipient families to start and operate an enterprise. If the government makes the regulation flexible regarding savings and credit products of MFIs/NGOs, then the MFIs/NGOs can develop appropriate savings, credit and insurance products for remittance recipient families. The Government can also establish Investment Company to channel more capital through MFIs/NGOs to the remittance recipient families which are operating enterprise.

- Creating Enabling environment to invest Remittances in Capital Market: Moreover, the government can make easy access to the capital market for the remittance recipient families. Although at present there is a provision for quota of foreign investors or nonresident Bangladeshis during Initial Public Offering(IPO) of issuing shares, but this process is so critical that most of the time this quota doesn't fulfilled. The government should make this quota system of issuing IPO also applicable for the families of the non-resident Bangladeshis, so that they can invest in the capital market.

\section{Conclusion}

Blessings of microfinance started by the father of modern microfinance, 2006 year's Nobel peace laureate; Professor Dr. Muhammad Yunus showed the way how to save the poor nation from such vulnerability situation. Yunus believed that microfinance is the proper way to save the poor nation from this catastrophic situation. Microfinance service provides credit to the poor without collateral. Yunus'sGrameen Model is one of the best ways to transfer the microfinance services into a social mechanism system which ultimately streamline the poor people into the socioeconomic development of the country and which are the reflections of today's Bangladesh in the world. Microfinance services help the poor people not only to survive but also make them productive, selfemployed. Microfinance service has much contribution to Bangladesh's key economic development indicators, because it helps to increase GDP, GNP, Savings, etc. Penniless people who did not have any collateral are becoming self-employed by getting microfinance services. Microfinance reduces poverty by increasing per capital consumption among program participants and their families (Shahidur R. Khandker, 1998). As a result, the poor are coming above the Poverty Line and eventually help to increase the GDP, savings, etc. accordingly. For instance, the Grameen Bank's recent internal survey shows that, 68 percent of Grameen borrowers' families have crossed the Poverty Line, the remaining are moving steadily towards the Poverty Line from below.

\section{References}

[1] Alamgir, D. A. H. 1999. Micro financial Services in Bangladesh: Review of Innovations and Trends. Dhaka: Credit and Development Forum.

[2] Asian Development Bank (ADB). 1998. Report and Recommendation of the President to the Board of Directors on a Proposed Loan and Technical Assistance Grant to the People's Republic of Bangladesh for the Rural Livelihood Project. Manila: ADB.

[3] Berenbach, S., and C. Churchill. 1997. Regulation and Supervision of Microfinance Institutions: Experience from Latin America, Asia, and Africa. The Microfinance Network (MFN) Occasional Paper No. 1. Washington, D.C.: MFN.

[4] Carpenter, J. 1997. Bangladesh. In Regulation and Supervision of Microfinance Institutions. The Microfinance Network (MFN) Occasional Paper No. 2, edited by Craig Churchill.

[5] Choudhury, S. H. 2002. Comments taken from May 2002 interview with S. Charitonenko and S. M. Rahman.

[6] Christen, R. P. 2000. Commercialization and Mission Drift: The Transformation of Microfinance in Latin America. Occasional Paper No. 5, Washington, D. C.: Consultative Group to Assist the Poorest.

[7] Cracknell, D. 2000. Microfinance Regulation in Bangladesh - A Long Path to Progress. Small Enterprise Development 11(4). London: ITDG Publishing. Credit and Development Forum (CDF). 2001a. CDF Statistics (June 2001 draft). Dhaka: CDF.

[8] Fleisig, H. 1996. Secured Transactions: The Power of Collateral. Finance and Development 33(2): 44-46.

[9] Goodwin-Groen, R. 1998. The Role of Commercial Banks in Microfinance. Brisbane: Foundation for Development Cooperation.

[10] Grameen Bank. 2011. Annual Report 2011. Dhaka: Grameen Bank.

[11] Hashemi, S. 1997. Those Left Behind: A Note on Targeting the Hardcore Poor. In Who Need Credit? 